\title{
ANTROPOMETRIC CHARACTERISTICS AND BODY COMPOSITION OF LATINOAMERIC DANCERS OF SERBIA
}

\author{
Dragana Labudović ${ }^{1}$, Sanja Mandarić2 ${ }^{2}$ Marija Macura², Lidija Moskovljević \\ ${ }^{1}$ Densing Club «Calypso» Belgrade, Serbia \\ ${ }^{2}$ University of Belgrade, Faculty of Sport and Physical Education, Serbia
}

\begin{abstract}
Latin American dances, at a dance sport competitions, consist of five couple dances, different in performance, character and tempo of music: samba, cha-cha, rumba, paso doble and jive. The influence on achievement in sports dance has certain morphological characteristics of dancers from two aspects, functional and aesthetic. The aim of this paper was to measure certain anthropometric dimensionalities using the standard procedures on a suitable sample and determine the body composition of Latin American dancers of the first federal rank of Serbia. For the purpose of the research, 16 anthropometric variables and a specific body composition were measured, using the equations of the program by Matejka (Mateigki). The obtained data were processed with descriptive statistical indicators, while one-factor analysis of variance (ANOVA) was applied from the space of comparative statistics. The results showed that the dancers are moderately slim and have a balanced physical structure of the body, that there are certain differences in relation to gender, and that there are no statistically significant differences in dimensionality and body composition compared to age categories in both genders. The results obtained are in accordance with previous research.
\end{abstract}

Keywords: ANTROPOMETRY / MORPHOTYPE / SPORT DANCE / PHYSICAL COMPOSITION / ART SPORTS

\section{INTRODUCTION}

Sport dance involves the use of dances in the system of sports competitions, whereby the dance is standardized in terms of special rules on competitions, dances, costumes, judges and other elements (Labudović, 2015). According to the International Dance Federation, sports dance represents a physical activity that combines sports and dance, influences the development of physical fitness, the achievement of mental stability and socialization of the individual (https://www.worlddancesport.org/About/All). In the classification of sports, because of their specificity of performance, dances are included in artistic sports.

The dance sport competition system consists of three dance sport disciplines of couple dances: Latin American dances, Standard dances and a combination of 10 dances. Latin American dances are tem- peramental, lively, fast dancing, which corresponds to the characteristics of the people of that region (Jocić, 1999, p. 128). It also contributes to music, with a specific rhythmic section in which the old African instruments (claves, maracas, bongos, timbals, various drums) are used, which formed the melodies of these dances (Milidrag, 1998). The category of Latin American dances consists of five dances: samba, chacha-cha, rumba, paso doble and jive. Unlike Standard dances, they are much more energetic and more versatile, while each dance has its own specific technique and pace of performance, where the character of each dance must be recognizable during performance. Latin American dances, as a discipline of dance sport, represent a polystructural sports branch, distinctly acyclic, with the specifics of each individual dance. 
Complexity also increases movement in all three levels of the body in the technique of performing dances, where each part of the body has a specific technique of movement, as well as the performance of figures in couple. For optimum performance, dancers should have a high degree of aesthetic and technical expression, as well as psychological preparation in order to handle stress in a critical situation, without injury and in a great physical form (Liiv, 2014; Liiv et al., 2013B).

Research in sports science points out that certain morphological characteristics have an impact on the success of athletes in achieving results (Taboada-Iglesias, Santana, \& Gutiérrez-Sánchez, 2017), and consequently on the results of dance sport, in which this component has a dual effect, aesthetic and functional. The aesthetic effect is expressed through the coherence of the dancers' background and the compatibility of partner morphotypes. The functional effect is manifested through the performance of complex polystructural motions with optimal speed, precision and perseverance.

The body composition of athletes is of great importance for sports efficiency. It differs from the composition of the "conditional man" and "conditional woman", as well as between athletes of different sports branches. This difference is caused by the specifics of training and the demands of the sports branch itself, from the aspect of motor skills. Also, anthropometric dimension measurements play an important role in the selection and criteria of sports achievement in a particular sports branch. In dance sport, these criteria also apply to the aesthetic component (Liiv et al., 2013 A; Liiv et al., 201B). There are no data on body composition and anthropometric measures that dancers of Latin American dances should possess, but an increasing number of studies in this field indicate the need to set up a desirable model of Latin American dancers of both genders to respond to the requirements of both domains, aesthetic and functional. For dancers, who are a special group of athletes, the optimal composition of the body serves as a means of achieving the physiological needs of a healthy body and the aesthetic goal of "leanness" in order to achieve maximum performance on the scene (Yannakoulia, Keramopoulos, Tsakalakos, \& Matalas, 1999), what started the research in this area.

The research conducted by Mikhailov \& Raschka (2010) included 29 male and 32 female dancers of
Latin American dances, divided into four groups by gender and dance level, and the anthropometric and sports-constitutional differences of male and female dancers in Latin American dances depending on their level of performance. The data show that most of the anthropometric values of dancers at higher dance levels are lower than those of lower-level dancers (at the same average body height of about $179 \mathrm{~cm}$, men with a higher level of performance have a lower weight (70.7 kg compared to $75.6 \mathrm{~kg}$ ) The research of the dancers did not produce any significant results depending on the level of performance, but most of the values of female athletes reveal a growth trend in contrast to dancers at lower levels of performance. The conclusion of the survey was that average competitors, regardless of gender and level, own balanced physical structure of the body (Mikhailov \& Raschka, 2010).

Several studies, conducted by Liiv with associates, have investigated variations in somatotype and anthropometry in various dance disciplines. A study comparing Latin American dancers, Standard dancers and dancers in combination of 10 dances showed that dancers of Latin American dances were a bit shorter with a smaller range of hands than Standard dancers (Liiv et al., 2013B; Liiv, 2014). In the second study from the same year, the difference between the anthropometric characteristics of contemporary ballet dancers, classical ballet dancers and Latin American dancers was examined. The results showed that contemporary ballet dancers have more muscular structure than classical ballet dancers, while Latin American dancers are slightly taller and heavier, with less muscle mass and greater percentage of body fat mass in body composition (Liiv et al., 2013A; Liiv, 2014).

Also, a study of 2015, featuring 19 female and 16 male dancers explored the anthropometric and somatotype differences of Latin American dancers in Germany compared to the gym practitioners. The results showed that average body weight and body mass index were higher in gym practitioners compared to dancers in both genders, while the measured body fat percentage was higher for dancers of both genders (Raschka \& Beyer, 2015).

Interesting is research with the aim of constructing and validating the equation of predicting the estimation of the body composition of the dancers, using 
the bioelectric impedance analysis (BIA) as an estimation method, and the Dual x-ray absorptiometry (DXA) as a criterion method. This research includes 42 female dancers, students of the dance university. The results showed that the non-fat component in dancers makes, on average, $42.6 \mathrm{~kg}$, while the average value of the percentage of fat tissue is $19.4 \%$, which represents a value that is in the range of $17-23 \%$ of body fat that is considered optimal for dancers (Yannakoulia et al., 1999).

A survey conducted in Poland included 20 elite Latin American dancers, and showed that $80 \%$ of female dancers belong to the athletic body type, while the remaining $20 \%$ are dancers with a picnic type. In male dancers this ratio is $60 \%$ leptosome (asthenic) type, and $40 \%$ athletic body type (Pilewska, Pilewski, \& Zukow, 2013).

The importance of morphological characteristics for optimal performance in aesthetic sports is observed in most models of the sport analysis system. By analyzing the morphotype of the dancers, as well as by comparing it with the model and the results of the general population, parameters can be obtained that give important data regarding the competitive performance of the dancers. The subject of this research was the anthropometric measurements and the body composition of Latin American dancers in Serbia, while the aim of the research was to determine the body composition of Latin American dancers in Serbia, using anthropometric measurements and formula by Mateigki.

\section{METHOD}

In accordance with the subject, the goal and the nature of the problem, the population of Latin American dancers of Serbia were tested. Respondents belong to the A and B class of the first federal rank, and two age categories, youth and seniors. The research used theoretical analysis and descriptive scientific research method.

\section{Sample}

For the research, a suitable sample was used that included 23 respondents aged $20.04 \pm 3.77$ years. The research was realized in three dance clubs from Belgrade, dance clubs "Best”, „Dare to dance” and "Calypso". The total sample consisted of 23 competitors: 9 male dancers ( 3 from the youth category of and 6 from the senior category) and 14 female dancers (8 from youth and 6 from senior category). The survey included male and female dancers who voluntarily participated in the study.

\section{Variables}

For the purpose of the research, the 16 anthropometric variables necessary for determination morphological characteristics of Latin American dancers were measured and they include: body height $(\mathrm{cm})$, body weight $(\mathrm{kg})$, upper arm circumference $(\mathrm{cm})$, forearm circumference $(\mathrm{cm})$, thigh circumference $(\mathrm{cm})$, lower leg circumference $(\mathrm{cm})$, wrist diameter $(\mathrm{cm})$, elbow diameter $(\mathrm{cm})$, knee diameter $(\mathrm{cm})$, ankle joint diameter $(\mathrm{cm})$, biceps skin fold $(\mathrm{mm})$, forearm skin fold $(\mathrm{mm})$, upper leg skin fold $(\mathrm{mm})$, lower leg skin fold $(\mathrm{mm})$, breast skin fold $(\mathrm{mm})$ and stomach skin fold $(\mathrm{mm})$, as well as body mass index (BMI). Independent variables represent the gender and age of competitors.

Standard measurements were followed during measurement. For the circumference of the forearm and upper arm, as well as for skin folds, the mean value of the three consecutive measurements was recorded. The body mass index (BMI) is calculated as a weight ratio $(\mathrm{kg})$ and height square $(\mathrm{m})$. Body composition (percentage of fat, muscle and bone tissue in total body mass) was calculated using the equations of the program by Matejka (Mateigki) based on the measured anthropometric variables according to the International Biological Program - IBP, in standardized conditions. The advantage of Matejka's method is that, in addition to the percentage of body fat and bones, it counts the percentage of muscles in the body composition (Stojiljković, Mitić, Mandarić, and Nešić, 2012).

\section{Statistical data processing}

The selected methods are in accordance with the subject, tasks, nature of the problem and hypotheses. The research used theoretical analysis and descriptive scientific research method. The results of the research were processed with the following descriptive statisti- 
cal indicators: mean value, standard deviation, minimum and maximum values, while one-factor analysis of variance (ANOVA) was applied from the space of comparative statistics. The results were processed with the statistical software IBM SPSS 24.0.

\section{RESULTS}

\section{Body composition}

The body composition of Latin American dancers of Serbia was determined on the basis of anthropometric measurement and applied equations. Standard descriptive statistics of anthropometric variables for both genders and ages are presented.

Table 1. Descriptive statistics of anthropometric variables

\begin{tabular}{|c|c|c|c|c|c|c|c|c|c|c|c|c|}
\hline & \multicolumn{2}{|c|}{$\begin{array}{l}\text { Male Dancers } \\
\qquad(\mathrm{H}=9)\end{array}$} & \multicolumn{2}{|c|}{$\begin{array}{l}\text { Male youth } \\
\qquad(\mathbf{H}=3)\end{array}$} & \multicolumn{2}{|c|}{$\begin{array}{l}\text { Male seniors } \\
\qquad(\mathrm{H}=6)\end{array}$} & \multicolumn{2}{|c|}{$\begin{array}{l}\text { Female dancers } \\
\qquad(\mathbf{H}=14)\end{array}$} & \multicolumn{2}{|c|}{$\begin{array}{l}\text { Female youth } \\
\qquad(\mathrm{H}=8)\end{array}$} & \multicolumn{2}{|c|}{$\begin{array}{l}\text { Female seniors } \\
\qquad(\mathrm{H}=6)\end{array}$} \\
\hline & $\mathrm{AM}$ & SD & $\mathrm{AM}$ & SD & $\mathrm{AM}$ & $\mathrm{SD}$ & $\mathrm{AM}$ & SD & $\mathrm{AM}$ & SD & $\mathrm{AM}$ & $\mathrm{SD}$ \\
\hline Age & 21,44 & 4,30 & 17,33 & 1,15 & 23,50 & 3,73 & 19,14 & 3,39 & 16,63 & 0,74 & 22,50 & 2,35 \\
\hline TV & 1,80 & 0,04 & 1,82 & 0,06 & 1,79 & 0,03 & 1,66 & 0,07 & 1,68 & 0,07 & 1,63 & 0,06 \\
\hline TM & 76,90 & 3,65 & 75,50 & 2,38 & 77,60 & 4,16 & 58,49 & 8,47 & 59,45 & 10,45 & 57,22 & 5,49 \\
\hline BFBIA & 8,39 & 2,87 & 8,17 & 2,00 & 8,50 & 3,40 & 19,95 & 3,49 & 20,64 & 3,94 & 19,03 & 2.84 \\
\hline BMI & 23,87 & 1,76 & 22,91 & 1,27 & 24,34 & 1,86 & 21,15 & 2,00 & 20,89 & 2,54 & 21,50 & 1,07 \\
\hline OPOTK & 39,90 & 1,06 & 39,83 & 0,91 & 39,93 & 1,21 & 36,46 & 3,26 & 35,94 & 3,66 & 37,15 & 2,81 \\
\hline OPODL & 25,42 & 2,33 & 23,47 & 3,05 & 26,40 & 1,22 & 22,51 & 1,68 & 22,48 & 204 & 22,55 & 1,24 \\
\hline ONATK & 57,80 & 6,99 & 55,07 & 7,73 & 59,17 & 6,89 & 56,30 & 4,45 & 56,80 & 5,00 & 55,62 & 3,94 \\
\hline ONADL & 31,07 & 1,53 & 31,33 & 0,91 & 30,93 & 1,84 & 26,25 & 2,68 & 26,30 & 3,30 & 26,18 & 1,84 \\
\hline DRUČ & 5,83 & 0,23 & 5,90 & 0,17 & 5,80 & 0,26 & 5,16 & 0,36 & 5,15 & 0,41 & 5,18 & 0,31 \\
\hline DLAK & 6,78 & 0,53 & 7,20 & 0,36 & 6,57 & 0,48 & 5,87 & 0,38 & 5,88 & 0,38 & 5,87 & 0,40 \\
\hline DKOL & 10,10 & 0,49 & 10,17 & 0,35 & 10,07 & 0,58 & 8,93 & 0,57 & 8,94 & 0,59 & 8,92 & 0,59 \\
\hline DSKOČ & 7,56 & 0,45 & 7,70 & 0,26 & 7,48 & 0,53 & 6,61 & 0,32 & 6,58 & 0,37 & 6,65 & 0,27 \\
\hline DKNBI & 6,97 & 1,79 & 6,77 & 1,59 & 7,07 & 2,02 & 9,01 & 2,06 & 9,41 & 2,30 & 8,48 & 1,73 \\
\hline DKNPODL & 6,96 & 1,96 & 6,57 & 1,99 & 7,15 & 2,11 & 9,06 & 3,28 & 10,24 & 3,79 & 7,48 & 1,67 \\
\hline DKNNATK & 12,44 & 5,52 & 13,30 & 6,52 & 12,02 & 5,58 & 13,43 & 3,93 & 14,90 & 4,04 & 11,47 & 3,02 \\
\hline DKNPOTK & 8,66 & 3,38 & 7,10 & 3,05 & 9,43 & 3,53 & 12,14 & 2,92 & 12,18 & 3,22 & 12,10 & 2,77 \\
\hline DKNGR & 11,60 & 2,93 & 10,23 & 1,93 & 12,28 & 3,25 & 9,04 & 1,74 & 9,24 & 2,04 & 8,78 & 1,37 \\
\hline DKNTR & 13,50 & 3,84 & 13,17 & 4,15 & 13,67 & 4,08 & 15,16 & 3,44 & 14,85 & 3,18 & 15,57 & 4,03 \\
\hline BFM & 16,57 & 4,49 & 16,01 & 4,83 & 16,84 & 4,76 & 20,70 & 3,38 & 21,57 & 3,40 & 19,55 & 3,27 \\
\hline BNM & 16,11 & 1,48 & 17,33 & 1,31 & 15,51 & 1,22 & 15,16 & 1,23 & 15,14 & 1,32 & 15,20 & 1,21 \\
\hline MSM & 49,41 & 3,73 & 47,97 & 1,76 & 50,13 & 4,38 & 48,06 & 3,03 & 47,36 & 3,09 & 48,99 & 2,95 \\
\hline
\end{tabular}

Legend: $\mathrm{n}$ - number of respondents, AS - arithmetic mean, SD - standard deviation, TV - body height, TM - body weight, BFBIA - body fat percentage measured by BIA method, BMI - body mass index, OPOTK - lower leg circumference, OPODL - forearm circumference, ONATK - thigh circumference, ONADL - upper arm circumference, DRUČ - wrist diameter, DLAK - elbow diameter, DKOL - knee diameter, DSKOČ - ankle joint diameter, DKNBI biceps skin fold, DKNPODL - forearm skin fold, DKNNATK - upper leg skin fold, DKNPOTK - lower leg skin fold, DKNGR - breast skin fold, DKNTR - stomach skin fold, BFM - percentage of fat tissue by Matejka, BNM - percentage of bone tissue by Matejka, MSM - percentage of muscle mass by Matejka. 
Table 1 shows descriptive parameters on a total sample of 9 male and 14 female dancers of Latin American dances, as well as values by age category. The results of the body composition, calculated by Matejka's equations, show that the average value of the percentage of fat tissue in the male dancers is $16.57 \%$ \pm 4.49 (on the sub-sample of youth it is $16.01 \pm 4.8$ and the senior $16.84 \pm 4.76$ ) , bone tissue $16.11 \% \pm$ 1.48 (on the sub-sample of youth it amounts to 17.33 \pm 1.31 and seniors $15.51 \pm 1.22$ ) and muscles $49.41 \%$ \pm 3.73 (on the sub-sample of youth it is $47.97 \pm 1.76$ and seniors $50.13 \pm 4.38$ ). The average value of the percentage of fat tissue in female dancers is $20.70 \%$ \pm 3.38 (on the sub-sample of youth it is $21.57 \pm 3.40$ and the seniors $19.55 \pm 3.27$ ), bone tissue $15.16 \% \pm$ 1.23 (youth $15.14 \pm 1.32$ and senior $15.20 \pm 1.21$ ) and muscle $48.06 \% \pm 3.03$ (on the sub-sample of youth it amounts to $47.36 \pm 3.09$ and senior $48.99 \pm 2.95$ ).

The male dancers show that the height of the entire sample $(1.80 \pm 0.04)$ is in the range of the average height of the men of Serbia, while the results by age indicate that the average height of the youth $(1.82 \pm$ $0.06)$ is greater the value of the senior $(1.79 \pm 0.03)$. It is also interesting to note that the results of the percentage of body fat measured by different methods differ significantly, with the impedance being lowered (8.39), and the equation by Matejka is about twice the value (16.57). Female dancers are also in the range of average heights for women. The results show that the values of the percentage of muscle mass are above the values of the „conditional man” and „conditional woman”, according to Ugarković (Ugarkovic, 2004, p. 54).

\section{Connection of anthropometric parameters by sex and age}

The assumption was that there were statistically significant differences between the body composition of the male and female dancers of Latin American dances in the overall sample.

Table 2. Comparative statistical indicators

\begin{tabular}{|c|c|c|c|c|c|c|c|c|c|c|c|c|}
\hline & \multicolumn{4}{|c|}{ Male dancers - female dancers } & \multicolumn{4}{|c|}{ Male youth - male seniors } & \multicolumn{4}{|c|}{ Female youth - female seniors } \\
\hline & df & $\begin{array}{l}\text { Mean } \\
\text { Square }\end{array}$ & $\mathbf{F}$ & $\mathbf{p}$ & df & $\begin{array}{l}\text { Mean } \\
\text { Square }\end{array}$ & $\mathbf{F}$ & $\mathbf{P}$ & df & $\begin{array}{l}\text { Mean } \\
\text { Square }\end{array}$ & $\mathbf{F}$ & $\mathbf{p}$ \\
\hline TV & 1 &, 102 & 29,275 &, $000^{* *}$ & 1 & 0,002 & 1,050 & 340 & 1 & 0,009 & 2,261 & , 159 \\
\hline $\mathrm{TM}$ & 1 & 1856,160 & 37,518 &, $000^{* *}$ & 1 & 8,820 & 0,631 & 453 & 1 & 17,101 & 0,224 & ,644 \\
\hline BFBIA & 1 & 732,220 & 68,644 &, $000^{* *}$ & 1 & 0,222 & 0,024 & ,882 & 1 & 8,823 & 0,709 & ,416 \\
\hline BMI & 1 & 40,377 & 11,042 &, $003^{* *}$ & 1 & 4,109 & 1,396 & ,276 & 1 & 1,306 & 0,309 & ,589 \\
\hline OPOTK & 1 & 64,935 & 9,244 &, $006^{* *}$ & 1 & 0,020 & 0,016 & ,904 & 1 & 5,041 & 0,453 &, 514 \\
\hline OPODL & 1 & 46,553 & 12,219 &, $002^{\star *}$ & 1 & 17,209 & 4,621 & ,069 & 1 & 0,019 & 0,006 & ,938 \\
\hline ONATK & 1 & 12,444 & ,403 &, 532 & 1 & 33,620 & 0,659 & ,444 & 1 & 4,801 & 0,228 & ,642 \\
\hline ONADL & 1 & 127,097 & 23,802 &, $000^{\star *}$ & 1 & 0,320 & 0,121 &, 738 & 1 & 0,047 & 0,006 & 940 \\
\hline DRUČ & 1 & 2,452 & 24,852 &, $000^{* *}$ & 1 & 0,020 & 0,350 &, 573 & 1 & 0,004 & 0,028 & ,871 \\
\hline DLAK & 1 & 4,500 & 23,253 &, $000^{\star \star}$ & 1 & 0,802 & 3,918 & ,088 & 1 & 0,000 & 0,002 & ,969 \\
\hline DKOL & 1 & 7,518 & 25,759 &, $000^{* *}$ & 1 & 0,020 & 0,073 & ,795 & 1 & 0,001 & 0,004 & ,949 \\
\hline DSKOČ & 1 & 4,928 & 35,060 &, $000^{* *}$ & 1 & 0,094 & 0,430 &, 533 & 1 & 0,019 & 0,177 & ,682 \\
\hline DKNBI & 1 & 22,969 & 5,971 &, $023^{*}$ & 1 & 0,180 & 0,049 &, 830 & 1 & 2,960 & 0,681 & ,425 \\
\hline DKNPODL & 1 & 24,196 & 2,973 & ,099 & 1 & 0,681 & 0,158 & ,703 & 1 & 26,007 & 2,736 & ,124 \\
\hline DKNNATK & 1 & 5,306 & ,251 & ,622 & 1 & 3,294 & 0,096 & ,766 & 1 & 40,415 & 3,033 & , 107 \\
\hline
\end{tabular}


Labudović D., et. al., Antropometric Characteristics and..., PHYSICAL CULTURE 2018; 72 (2): 202-210

\begin{tabular}{lccccccccccccc} 
DKNPOTK & 1 & 66,623 & 6,904 &, $016^{*}$ & 1 & 10,889 & 0,944 &, 364 & 1 & 0,019 & 0,002 &, 964 \\
DKNGR & 1 & 35,822 & 6,970 &, $015^{*}$ & 1 & 8,405 & 0,977 &, 356 & 1 & 0,707 & 0,220 &, 648 \\
DKNTR & 1 & 15,044 & 1,161 &, 293 & 1 & 0,500 & 0,030 &, 868 & 1 & 1,761 & 0,139 &, 716 \\
BFM & 1 & 93,740 & 6,360 &, $020^{*}$ & 1 & 1,389 & $0, .061$ &, 812 & 1 & 13,938 & 1,244 &, 287 \\
BNM & 1 & 4,946 & 2,800 &, 109 & 1 & 6,613 & 4,244 &, 078 & 1 & 0,010 & 0,006 &, 939 \\
MSM & 1 & 10,059 &, 915 &, 350 & 1 & 9,360 & 0,642 &, 449 & 1 & 9,105 & 0,990 &, 339 \\
\hline
\end{tabular}

${ }^{*}$ Statistically significant difference on level $.05 ;{ }^{* *}$ statistically significant difference on level .01 Legend: $\mathrm{df}$ - degree of freedom, Mean Square - arithmetic mean of squares, F - coefficient of variance, p - significance, TV - body height, TM - body weight, BFBIA - percentage of body fat measured BIA method, BMI - body mass index, OPOTK - circumference of the lower leg, OPODL - forearm circumference, ONATK - thigh circumference, ONADL - upper arm circumference, DRUČ - wrist diameter, DLAK - elbow diameter, DKOL - knee diameter, DSKOČ - ankle joint diameter, DKNBI - biceps skin fold, DKNPODL - forearm skin fold, DKNNATK - upper leg skin fold, DKNPOTK - lower leg skin fold, DKNGR - breast skin fold, DKNTR - stomach skin fold, BFM - percentage of fat tissue by Matejka, BNM - percentage of bone tissue by Matejka, MSM - percentage of muscle mass by Matejka.

The results in Table 2 show that the percentage of body fat is the only one of the three components of the body composition that shows statistically significant difference in relation to sex at the level of significance .05 . The percentage of bone tissue and muscle does not show a statistically significant difference. Of the measured values of anthropometric measures, a statistically significant difference are in the body height, body weight, percentage of fat tissue measured by the BIA method, body mass index, lower leg circumference, forearm and upper arm and all four diameters at the level of significance .01. The skin folds of the lower leg and breast shows a statistically significant difference on the level of significance .05. In other measures, there is no statistically significant difference.

It was also assumed that there was no statistically significant difference between the results of male and female dancers of two age categories, youth and senior, which was a result analysis and confirmed by both genders.

\section{DISCUSSION}

The aim of the research was to determine the body composition of the Latin American dancers of the highest competitive class in Serbia. The survey sample comprised 23 respondents (male dancers, $\mathrm{n}=9$; female dancers, $n=14$ ). The entire sample, 23 respondents, are active competitors for many years.

The results showed that BMI has a mean value be- low 25 for both genders and all four sub-samples, and it can be said that dancers have normal nutrition (according to Stojiljković et al., 2012, p. 331). Also, the results of the percentage of fat tissue in male dancers ( $16.57 \%$ by Matejka) and female dancers $(20.70 \%$ by Matejka) show that the respondents are in the gender and age limit, accounting for $12-20 \%$ for men and 17 - 26\% for women (Stojiljković et al., 2012, p. 329), or 8-20\% for men aged $18-39$ and $21-33 \%$ for women aged 18-39 (Ostojić, cited according to Stojiljković et al., 2012, p. 329). If we compare the results obtained with the body composition, they are in line with the previous research in female dancers, while the male dancer has a small difference. The mean percentage of body fat in Latin American male dancers in Serbia is $16.57 \% \pm 4.49$, which is slightly higher than in previous studies in which this percentage was $12.9 \%$ \pm 3.4 (Raschka \& Beyer, 2015) $13.06 \% \pm 4.33$ (Liiv et al., 2013A), 13.4\% \pm 3.3 (Liiv et al., 2013B) and 14.4\% \pm 6.9 (Mikhailov \& Raschka, 2010). When it comes to female dancers, the average value of fat percentage in the research of Serbian competitors was $20.70 \% \pm$ 3.40 , which is fully in line with previous studies in which this value was $21.3 \% \pm 3.2$ (Yannakoulia et al., 1999), $21.8 \% \pm 4.6$ (Raschka \& Beyer, 2015), $21.92 \%$ \pm 3.74 (Liiv et al., 2013A), 22.5\% \pm 3.2 (Mikhailov \& Raschka, 2010) and 22.6\% \pm 5.6 (Liiv et al., 2013B). Serbian female dancers show a slightly lower percentage of fat percentage compared to previous research. If we look at the BMI score in all studies, its value for male dancers in Serbia is 23.87 while in other studies it ranges from 22.0 to 23.1 (Raschka \& Beyer, 2015; Liiv et al , 2013A; Liiv et al., 2013B; Mikhailov \& Ra- 
schka, 2010), which is in line with the differences in the values of the percentage of body fat that is higher for dancers in Serbia. In Serbian female dancers, the BMI average was 21.5 while in other researches it ranged from 19.9 to 22.0 (Liiv et al., 2013A; Liiv et al., 2013B; Mikhailov \& Raschka, 2010; Raschka \& Beyer, 2015; Yannakoulia et al., 1999), which points to the agreement between female dancers of other regions.

A comparison of the values of body fat percentage measured by different methods showed great differences in values obtained by different methods in Latin American male dancers of Serbia, with bioelectric impedance yielding lower values (8.39) from Matejka's equation (16.57). Since the BMI values of Serbian male dancers are higher than others, these differences can be the subject of some future research. The results of female dancers are approximately the same in both methods (19.95 and 20.70).

When it comes to gender differences, the assumption was that there will be differences in all parameters. However, only the percentage of body fat showed a statistically significant difference in the methods of bioelectric impedance and by Matejka, while the percentage of bone and muscle tissue does not show a statistically significant difference. This is not in line with previous research because the observations of previous studies showed clear gender specific differences between male and female dance performers, reflected in transverse and circular dimensionality measures, skin folds, percentage of body fat, and the results of individual typology provisions (Liiv et al., 2013A; Liiv et al., 2013B; Mikhailov \& Raschka, 2010; Raschka \& Beyer, 2015).

The results of examining the existence of a difference between male dancers of different age categories showed that no parameter and component of the body composition shows a statistically significant difference between youth and senior male dancers, at the level of significance .05 . In previous studies, such comparisons were not made, but differences were found with respect to length of training, and they showed that there are several significant specific differences among male dancers of different dance levels: men at the higher dance level have lower body weight (not a statistically significant difference), higher positioned of sphyrion (more than $1.5 \mathrm{~cm}$ ), smaller chest width (about $1.4 \mathrm{~cm}$ ) and lower overall body fat per- centage ( $11 \%$ compared to $14 \%$ ) compared to men at a lower level of dysfunction (Mikhailov \& Raschka, 2010), which could be an idea for some future research in the difference between the different levels of Serbian male dancers on a larger sample.

The results of examining the existence of a difference between female dancers of different age categories showed that no parameter and component of the body composition shows a statistically significant difference between youth and senior female dancers at the level of significance .05. Although there are no data from previous research related to this issue, there are data on the investigated differences between the different dance levels of Latin American female dancers. Female dancers, generally, show the opposite trend in relation to dancers at different dance levels. Female dancers at higher levels have a higher body mass (not significantly), a shorter hull (for the same average body height of about $166 \mathrm{~cm}$ ) and a higher percentage of total body fat (not significant). Most volumes reveal a trend of growth in contrast with female dancers of lower dance level (Mikhailov \& Raschka, 2010). Also, differences in relation to other dance styles indicate that Latin American dancers are a little bit taller and heavier, with less muscle mass and greater percentage of body composition as well as greater aerobic capacity compared to classical and contemporary ballet dancers (Liiv et al., 2013A; Liiv, 2014).

Different age of dancers in this study can be conditionally observed as different dance levels, since age is most often correlated with the length of training, and therefore with the level of performance. However, this study did not show any difference to the age of dancers in both sexes.

\section{CONCLUSION}

The conducted research, on a suitable sample of dancers, was the first to deal with the problem of the body composition of Latin American dancers in Serbia. The obtained results showed the structure of the body composition and the values of the measurement of anthropometric dimensionalities, characteristic for Latin American dancers of Serbia of the highest dance rank, both genders, in two age 
categories (youth and senior). It began from previous studies that determined the existence of moderately lean body composition of the dancers, as well as the difference in relation to the gender. The realized research confirmed the assumptions related to the body composition, the age differences in the same gender, and partly for the interval differences, on a sample of 23 dancers. Also, it was noticed that Latin American dancers are average body height and body weight, and the obtained measurement results are in line with previous research.

The sports result in the Latin American dance sport discipline depends on a number of external and internal factors, and the morphological structure of the dancers is just one of them. For this reason, only one-time anthropometric measurements are not sufficient. At the same time it is necessary to monitor the

\section{REFERENCES}

1. Jocić, D. (1999). Plesovi. [Dances, in Serbian]. Beograd: Fakultet fizičke kulture Univerziteta u Beogradu.

2. Labudović, D. (2015). Kvalitativna analiza Standardnih plesova [Qualitative analysis of Standard Dances, In Serbian]. Fakultet sporta i fizičkog vaspitanja. Beograd.

3. Liiv, H. (2014). Anthropometry, body composition and aerobic capacity in elite DanceSport athletes compared with ballet and contemporary dancers (Dissertationes Kinesiologiae Universitatis Tartuensis). Tartu: University of Tartu.

4. Liiv, H., Wyon, M. A., Jürimäe, T., Saar, M., Mäestu, J., \& Jürimäe, J. (2013A). Anthropometry, somatotypes, and aerobic power in ballet, contemporary dance, and dancesport. Medical Problems of Performing Artists, 28(4), 207 - 11.

5. Liiv, H., Wyon, M., Jürimäe, T., Purge, P., Saar, M., Mäestu, J., \& Jürimäe, J. (2013B). Anthropometry and somatotypes of competitive DanceSport participants: A comparison of three different styles. HOMO - Journal of Comparative Human Biology, 65(2), $155-160$.

6. Mikhailov, B., \& Raschka, C. (2010). Anthropometrical and Sport Consitutional Comparison of Male and Female Ballroom and Latin Dancers results of measurement, change their values and the impact of these changes on the mutual relationship of factors that include: body composition, functional abilities, technical level and results of the competition. Only in this way is it possible to perceive the connection between the components of the body composition and the sports achievement and to create the image of the ideal morphological model of the dancer we are trying to achieve.

\section{Note:}

The paper is a work of master dissertation: Labudović, D. (2018). Morphotype of competitors of Latin American dances of Serbia (Master dissertation). Faculty of Sport and Physical Education, Belgrade.

with Regard to Different Performance Levels. $\mathrm{Pa}$ pers on Anthropology, XIX, 2010, 258-270.

7. Milidrag, S. (1998). Плес: игра, покрет, ритам. [Dance: play, movement, rhythm, in Serbian]. Beograd, Svet knjige.

8. Pilewska, W., Pilewski, R., \& Zukow, W. (2013). Characteristics of Body Composition Highly Qualified Dancers and Dancers Latin American Style of Dance Sports in Light of Typology of Somatic A. Wanky and Kretschmer. Journal of Health Sciences (J for the Ss H), 3(5), 255-266.

9. Raschka, C., \& Beyer, K. (2015). Sports Anthropological and Somatotypical Investigation of Male and Female Latin Dancers. Papers on Anthropology, XXIV/2, 94-101.

10. Stojiljković, S., Mitić, D., Mandarić, S., i Nešić, D. (2012). Personalni fitnes. Beograd: Fakultet sporta i fizičkog vaspitanja Univerziteta u Beogradu.

11. Taboada-Iglesias, Y., Santana, M. V., \& GutiérrezSánchez, Á. (2017). Anthropometric Profile in Different Event Categories of Acrobatic Gymnastics. Journal of Human Kinetics, 57(2017), 169-179.

12. Ugarković, D. (2004). Biomedicinske osnove sportske medicine. [Biomedical basics of sports medicine, in Serbian]. Novi Sad: D. L. Ugarković, 2004 (Novi Sad: FB print). 
13. Yannakoulia, M., Keramopoulos, A., Tsakalakos, N., \& Matalas, A.L. (2000). Body composition in dancers: the bioelectrical impedance method. Medicine \& Science in Sports \& Exercize, 32(1), $228-234$.
14. DanceSport For All! (2018). World Dance Sport Federation. Available from 20.08.2018 at: https:// www.worlddancesport.org/About/All

\title{
CARACTERÍSTICAS ANTROPOMÉTRICAS Y COMPOSICIÓN CORPORAL DE LOS BAILARINES DE BAILES LATINOAMERICANAS EN SERBIA
}

\begin{abstract}
Extracto
Los bailes latinoamericanos, en las competencias de baile deportivo, abarcan los cinco bailes de pareja, diferentes por la técnica de interpretación, carácter y ritmo de la música: samba, chachachá, rumba, paso doble y jive. La influencia en los alcances en el baile deportivo tienen las determinadas características morfológicas de los bailarines partiendo de dos aspectos, el funcional y el estético. El objetivo del presente trabajo era medir, aplicando los procedimientos en una muestra conveniente, las determinadas dimensionalidades antropométricas y determinar la composición corporal de los bailarines de los bailes latinoamericanos del primer nivel de la federación de Serbia. Para la investigación se han medido las 16 variables antropométricas y la determinada composición corporal, utilizando las ecuaciones del programa por Matiegka. Los datos obtenidos se elaboraron por los indicadores estadísticos descriptivos, mientras que del espacio de la estadística comparativa se aplicó el análisis de varianza con un factor (ANOVA). Los resultados demostraron que los bailarines son de la composición corporal medio delgada y tienen la estructura física del cuerpo equilibrada, que existen ciertas diferencias en relación con el sexo, pero no en nivel esperado, como tampoco existen las diferencias estadísticamente importantes en las dimensionalidades y en la composición corporal en relación con las categorías de edades en ambos sexos. Los resultados obtenidos están de acuerdo con las investigaciones previas.
\end{abstract}

Palabras claves: ANTROPOMETRÍA / TIPOS MORFOLÓGICOS / BAILE DEPORTIVO / COMPOSICIÓN CORPORAL / DEPORTES ARTÍSTICOS

Received: 02.10.2018.

Accepted: 24.12.2018. 


\title{
АНТРОПОМЕТРИЈСКЕ КАРАКТЕРИСТИКЕ И ТЕЛЕСНИ САСТАВ ПЛЕСАЧА ЛАТИНОАМЕРИЧКИХ ПЛЕСОВА СРБИЈЕ
}

\author{
Драгана Лабудовић ${ }^{1}$, Сања Мандарић², Марија Мацура ${ }^{2}$, Лидија Московљевић² \\ ${ }^{1}$ Плесни студио „Калипсо”, Београд \\ ${ }^{2}$ Универзитет у Београду, Факултет спорта и физичког васпитања
}

\begin{abstract}
Сажетак
Латиноамерички плесови, на такмичењима у спортском плесу, обухватају пет паровних плесова, различитих по техници извођења, карактеру и темпу музике: самбу, ча-ча-ча, румбу, пасо добле и џајв. Утицај на постигнуће у спортском плесу имају одређене морфолошке карактеристике плесача са два аспекта, функционалног и естетског. Циљ рада је био да се, применом стандардних процедура на пригодном узорку, измере одређене антропометријске димензионалности и одреди телесна композиција латиноамеричких плесача првог савезног ранга Србије. У циљу истраживања измерено је 16 антропометријских варијабли и одређен телесни састав, коришћењем једначина програма по Матејки (Mateigki). Добијени подаци су обрађени дескриптивним статистичким показатељима, док се из простора компаративне статистике, применила једнофакторска анализа варијансе (АНОВА). Резултати су показали да су плесачи умерено витке грађе и да имају уравнотежену физичку структуру тела, да постоје одређене разлике у односу на пол, као и да не постоје статистички значајне разлике у димензионалности и телесној композицији у односу на узрасне категорије код оба пола. Добијени резултати су у складу са претходним истраживањима.
\end{abstract}

Кључне речи: АНТРОПОМЕТРИЈА / МОРФОТИП / СПОРТСКИ ПЛЕС / ТЕЛЕСНА КОМПОЗИЦИЈА / УМЕТНИЧКИ СПОРТОВИ

\section{УвОД}

Спортски плес подразумева примену плесова у систему спортских такмичења, при чему је плес нормиран у смислу посебних правила о такмичењима, плесовима, костимима, судијама и другим елементима (Лабудовић, 2015). Према међународној плесној федерацији, спортски плес представља физичку активност која комбинује спорт и плес, утиче на развој физичке кондиције, постизање менталне стабилности и социјализације појединца (https://www.worlddancesport.org/About/All). У класификацији спортова, због својих специфичности извођења, плесови се убрајају у уметничке спортове.

Систем такмичења у спортском плесу се спроводи у три спортско - плесне дисциплине паровних плесова: латиноамерички плесови, стандардни плесови и комбинација 10 плесова.
Латиноамерички плесови су темпераментни, живи, брзи плесови, што одговара карактеристикама људи тог поднебља (Jocić, 1999). Томе доприноси и музика, са специфичном ритмичком секцијом у којој се користе стари афрички инструментим (клавес, маракас, бонгоси, тимбалеси, разни бубњеви), који су обликовали мелодије ових плесова (Милидраг, 1998). Категорију латиноамеричких плесова чини пет плесова: самба, ча-ча-ча, румба, пасо добле и џајв. За разлику од стандардних плесова, они су много енергичнији и са више окрета, док сваки плес има своју специфичну технику и темпо извођења, при чему карактер сваког појединачног плеса мора да буде препознатљив приликом извођења. Латиноамерички плесови, као дисциплина спортског плеса, представљају полиструктурну 
спортску грану, изразито ацикличног карактера, са специфичностима сваког појединачног плеса. Сложеност повећава и кретање у све три телесне равни у техници извођења плесова, при чему сваки део тела има специфичну технику кретања, као и извођење фигура у пару. За оптимално извођење, плесачи треба да поседују високи степен естетског и техничког испољавања, као и психолошку припрему да би поднели стрес у критичној ситуацији, без повреда и у одличној физичкој форми (Liiv, 2014; Liiv et al., 2013B).

Истраживања у науци о спорту истичу да одређене морфолошке карактеристике имају утицаја на успех спортиста у постизању резултата (Taboada-Iglesias, Santana, \& Gutiérrez-Sánchez, 2017), па самим тим и на резултате у спортском плесу, у којем ова компонента има двојаки ефекат, естетски и функционални. Естетски ефекат се испољава кроз складност грађе плесача и усклађеност морфотипова партнера. Функционални ефекат се испољава кроз извођење сложених полиструктуралних кретања оптималном брзином, прецизношћу и истрајношћу.

Телесна композиција спортиста има велики значај за спортску ефикасност. Она се разликује од композиције „условног човека“ и „условне жене“, као и између спортиста различитих спортских грана. Ова разлика је проузрокована специфичностима тренинга и захтева саме спортске гране, са аспекта моторичких способности. Такође, мере антропометријских димензионалности имају важну улогу у селекцији и критеријумима спортског постигнућа у одређеној спортској грани. У спортском плесу ти критеријуми се односе и на естетску компоненту (Liiv et al., 2013A; Liiv et al., 201B). Не постоје подаци телесног састава и антропометријских мера које би плесачи латиноамеричких плесова требало да поседују, али све већи број истраживања из ове области указује на потребу постављања пожељног модела латиноамеричких плесача оба пола, како би одговорили захтевима естетског и функционалног. За плесаче, оптимална композиција тела служи као „средство“ за постизање физиолошких потреба здравог тела и естетског циља „виткости“, како би се постигао максималан учинак на сцени (Yannakoulia, Keramopoulos, Tsakalakos, \& Matalas, 1999), због чега су и почела истраживања из ове области..

Истраживање које су спровели Михаилов и Рашка (Mikhailov \& Raschka, 2010) обухватило је 29 плесача и 32 плесачице латиноамеричких плесова, подељених у четири групе према полу и плесном нивоу, а испитивне су антропометријске и спортско-конституционалне разлике мушких и женских плесача у латиноамеричким плесовима у зависности од њиховог нивоа извођења. Подаци показују да је већина антропометријских вредности плесача на вишим плесним нивоима нижа него код плесача нижих нивоа (при истој просечној висини тела око 179 цм мушкарци са вишим нивоом извођења имају бољу (мању) тежину (70,7 кг у односу на 75,6 кг). Истраживање плесачица није дало никакве значајне резултате у зависности од нивоа извођења, али већина вредности спортисткиња открива тренд раста у контрасту са плесачицама на нижим нивоима извођења. Закључак истраживања је био да су просечни такмичари, независно од пола и нивоа, умерено витки са физичком структуром балансираног тела (Mikhailov \& Raschka, 2010).

Више студија, које је спровела Лив са сарадницима, истраживале су варијације у соматотипу и антропометрији у различитим плесним дисциплинама. Студија која је упоређивала плесаче латиноамеричких плесова, стандардних плесова и комбинације 10 плесова је показала да су плесачи латиноамеричких плесова нешто ниже грађе и мањег распона руку од плесача стандардних плесова (Liiv et al., 2013B; Liiv, 2014). У другој студији из исте године испитивана је разлика антропометријских карактеристика плесачица савременог балета, класичног балета и латиноамеричких плесова. Резултати су показали да су плесачице савременог балета са израженијом мускуларном грађом од балерина класичног стила, док су латиноамеричке плесачице нешто више и теже, са мањом мишићном масом и већим процентом масне компоненте телесног састава (Liiv et al., 2013A; Liiv, 2014).

Такође, студија из 2015. у којој је учествовало 19 плесачица и 16 плесача, истраживала је антропометријске и соматотипске разлике латиноамеричких плесача Немачке у односу на вежбаче у теретани. Резултати су показали да су просечна телесна тежина и индекс телесне масе виши код вежбача у теретани у односу на плесаче, код оба пола, док је измерен проценат телесних масти виши код плесача оба пола (Raschka \& Beyer, 2015).

Интересантно је истраживање, у којем су учествовале 42 професионалне плесачице, студенткиње плесног универзитета, са циљем да се конструише и валидира једначина предвиђања за процену састава тела код плесача, користећи 
анализу биоелектричне импедансе (БИА) као метод процене, при чему је као критеријумски метод коришћена двострука рендгенска апсорпциометрија (dual x-ray absorptiometry - DXA). Резултати су показали да безмасна компонента код плесачица чини, у просеку, 42,6 кг, док је просечна вредност процента масног ткива 19,4\%, што представља вредност која спада у опсег од 1723\% телесних масти који се сматра оптималним за плесачице (Yannakoulia et al., 1999).

Истраживање које је спроведено у Пољској обухватило је 20 елитних такмичара латиноамеричких плесова, а показало је да $80 \%$ плесачица припада атлетском типу грађе, а преосталих 20\% плесачица пикничком типу, док је код плесача овај однос 60\% лептозомном (астеничном) типу, а $40 \%$ атлетском типу грађе (Pilewska, Pilewski, \& Zukow, 2013).

Важност морфолошких карактеристика за оптимално извођење у естетским спортовима примећује се у већини модела система за анализу спорта. Анализом морфотипа плесача, као и његовим упоређивањем са моделом и резултатима опште популације, може се доћи до параметара који дају значајне податкеу вези са такмичарском ефикасношћу плесача. Предмет овог истраживања су биле антропометријске мере и телесна композиција латиноамеричких плесача Србије, док је циљ истраживања био одређивање телесног састава латиноамеричких плесача Србије, применом антропометријских мерења и формула по Матејки.

\section{МЕТОД}

У складу са предметом, циљем и природом проблема, у раду је испитана популација латиноамеричких плесача Србије, такмичара А и Б разреда првог савезног ранга, у две старосне категорије, старији омладинци и сениори. У истраживању су коришћене теоријска анализа и дескриптивна научно-истраживачка метода.

\section{Узорак испитаника}

За потребе истраживања коришћен је пригодан узорак који обухвата 23 испитаника узраста $20,04 \pm 3,77$ година. Истраживање се реализовало у три плесна клуба са подручја Београда, у плесном клубу „Бест“, „Dare to dance” и „Калип- со“. Укупан узорак је чинило 23 такмичара: 9 плесача (3 из категорије старијих омладинаца и 6 из категорије сениора) и 14 плесачица (8 из категорије старијих омладинки и 6 из категорије сениорки). Истраживањем су обухваћени плесачи и плесачице који су добровољно учествовали у испитивању.

\section{Узорак варијабли}

У циљу истраживања измерено је 16 антропометријских варијабли неопходних за одређивање морфолошких карактеристика латиноамеричких плесача које укључују: телесну висину (цм), телесну масу (кг), обим надлактице (цм), обим подлактице (цм), обим натколенице (цм), обим потколенице (цм), дијаметар ручног зглоба (цм), дијаметар лакта (цм), дијаметар колена (цм), дијаметар скочног зглоба (цм), дебљину кожног набора бицепса (мм), дебљину кожног набора подлактице (мм), дебљину кожног набора натколенице (мм), дебљину кожног набора потколенице (мм), дебљину кожног набора груди (мм) и дебљину кожног набора трбуха (мм), као и индекс телесне масе (БМИ). Независне варијабле представљају пол и узраст такмичара.

Приликом мерења праћене су стандардне процедуре. За обиме подлактице и надлактице, као и за дебљину кожних набора, бележена је средња вредност три узастопна мерења. Индекс телесне масе (БМИ) је рачунат као количник телесне масе (кг) и квадрата висине (м). Телесни састав (проценат масног, мишићног и коштаног ткива у укупној телесној маси) рачунат је коришћењем једначина програма по Матејки (Mateigki) на основу измерених антропометријских варијабли према Интернационалном биолошком програму - ИБП, у стандардизованим условима. Предност методе по Матејки је у томе што, поред процента телесне масти и костију, рачуна и проценат мишића у телесном саставу (Stojiljković, Mitić, Mandarić i Nešić, 2012).

\section{Статистичка обрада података}

Изабране методе су у складу са предметом, задацима, природом проблема и постављеним хипотезама. У истраживању су коришћене теоријска анализа и дескриптивна научно-истраживачка метода. Резултати истраживања обрађени су следећим дескриптивним статистичким показатељима: средња вредност, стандардна 
девијација, минимална и максимална вредност, док се из простора компаративне статистике применила једнофакторска анализа варијансе (АНОВА). Резултати су обрађени статистичким софтвером IBMSPSS 24.0.

\section{РЕЗУЛТАТИ}

\section{Телесни састав}

Телесни састав латиноамеричких плесача Србије утврђен је на основу антропометријског мерења и примењених једначина. Приказани су стандардни дескриптивни статистички индикатори антропометријских варијабли за оба пола и узраста.

Табела 1. Дескриптивна статистика антропометријских варијабли

\begin{tabular}{|c|c|c|c|c|c|c|c|c|c|c|c|c|}
\hline & \multicolumn{2}{|c|}{$\begin{array}{c}\text { Плесачи } \\
(\text { н = 9) }\end{array}$} & \multicolumn{2}{|c|}{$\begin{array}{c}\text { С.омладинци } \\
(\mathbf{H}=3)\end{array}$} & \multicolumn{2}{|c|}{$\begin{array}{c}\text { Сениори } \\
(\mathrm{H}=6)\end{array}$} & \multicolumn{2}{|c|}{$\begin{array}{c}\text { Плесачице } \\
\text { (н = 14) }\end{array}$} & \multicolumn{2}{|c|}{$\begin{array}{c}\text { С.омладинке } \\
(\text { н = 8) }\end{array}$} & \multicolumn{2}{|c|}{$\begin{array}{c}\text { Сениорке } \\
(\text { н = 6) }\end{array}$} \\
\hline & $\mathrm{AC}$ & СД & $\mathrm{AC}$ & СД & $\mathrm{AC}$ & СД & $\mathrm{AC}$ & СД & $\mathrm{AC}$ & СД & $\mathrm{AC}$ & СД \\
\hline Узраст & 21,44 & 4,30 & 17,33 & 1,15 & 23,50 & 3,73 & 19,14 & 3,39 & 16,63 & 0,74 & 22,50 & 2,35 \\
\hline TB & 1,80 & 0,04 & 1,82 & 0,06 & 1,79 & 0,03 & 1,66 & 0,07 & 1,68 & 0,07 & 1,63 & 0,06 \\
\hline TM & 76,90 & 3,65 & 75,50 & 2,38 & 77,60 & 4,16 & 58,49 & 8,47 & 59,45 & 10,45 & 57,22 & 5,49 \\
\hline БФБИА & 8,39 & 2,87 & 8,17 & 2,00 & 8,50 & 3,40 & 19,95 & 3,49 & 20,64 & 3,94 & 19,03 & 2.84 \\
\hline БМИ & 23,87 & 1,76 & 22,91 & 1,27 & 24,34 & 1,86 & 21,15 & 2,00 & 20,89 & 2,54 & 21,50 & 1,07 \\
\hline ОПОТк & 39,90 & 1,06 & 39,83 & 0,91 & 39,93 & 1,21 & 36,46 & 3,26 & 35,94 & 3,66 & 37,15 & 2,81 \\
\hline ОПОДЛ & 25,42 & 2,33 & 23,47 & 3,05 & 26,40 & 1,22 & 22,51 & 1,68 & 22,48 & 204 & 22,55 & 1,24 \\
\hline OHATK & 57,80 & 6,99 & 55,07 & 7,73 & 59,17 & 6,89 & 56,30 & 4,45 & 56,80 & 5,00 & 55,62 & 3,94 \\
\hline ОНАДЛ & 31,07 & 1,53 & 31,33 & 0,91 & 30,93 & 1,84 & 26,25 & 2,68 & 26,30 & 3,30 & 26,18 & 1,84 \\
\hline ДРУч & 5,83 & 0,23 & 5,90 & 0,17 & 5,80 & 0,26 & 5,16 & 0,36 & 5,15 & 0,41 & 5,18 & 0,31 \\
\hline ДЛАК & 6,78 & 0,53 & 7,20 & 0,36 & 6,57 & 0,48 & 5,87 & 0,38 & 5,88 & 0,38 & 5,87 & 0,40 \\
\hline ДКОЛ & 10,10 & 0,49 & 10,17 & 0,35 & 10,07 & 0,58 & 8,93 & 0,57 & 8,94 & 0,59 & 8,92 & 0,59 \\
\hline ДСКОЧ & 7,56 & 0,45 & 7,70 & 0,26 & 7,48 & 0,53 & 6,61 & 0,32 & 6,58 & 0,37 & 6,65 & 0,27 \\
\hline ДКНБИ & 6,97 & 1,79 & 6,77 & 1,59 & 7,07 & 2,02 & 9,01 & 2,06 & 9,41 & 2,30 & 8,48 & 1,73 \\
\hline ДКНПОДЛ & 6,96 & 1,96 & 6,57 & 1,99 & 7,15 & 2,11 & 9,06 & 3,28 & 10,24 & 3,79 & 7,48 & 1,67 \\
\hline ДКННАТК & 12,44 & 5,52 & 13,30 & 6,52 & 12,02 & 5,58 & 13,43 & 3,93 & 14,90 & 4,04 & 11,47 & 3,02 \\
\hline ДКНПОТК & 8,66 & 3,38 & 7,10 & 3,05 & 9,43 & 3,53 & 12,14 & 2,92 & 12,18 & 3,22 & 12,10 & 2,77 \\
\hline ДКНГР & 11,60 & 2,93 & 10,23 & 1,93 & 12,28 & 3,25 & 9,04 & 1,74 & 9,24 & 2,04 & 8,78 & 1,37 \\
\hline ДКНТР & 13,50 & 3,84 & 13,17 & 4,15 & 13,67 & 4,08 & 15,16 & 3,44 & 14,85 & 3,18 & 15,57 & 4,03 \\
\hline БФМ & 16,57 & 4,49 & 16,01 & 4,83 & 16,84 & 4,76 & 20,70 & 3,38 & 21,57 & 3,40 & 19,55 & 3,27 \\
\hline БНМ & 16,11 & 1,48 & 17,33 & 1,31 & 15,51 & 1,22 & 15,16 & 1,23 & 15,14 & 1,32 & 15,20 & 1,21 \\
\hline $\mathrm{MCM}$ & 49,41 & 3,73 & 47,97 & 1,76 & 50,13 & 4,38 & 48,06 & 3,03 & 47,36 & 3,09 & 48,99 & 2,95 \\
\hline
\end{tabular}

Легенда: н - број испитаника, АС - аритметичка средина, СД - стандардна девијација, ТВ - телесна висина, ТМ - телесна маса, БФБИА - проценат телесне масти мерен БИА методом, БМИ - индекс телесне масе, ОПОТК - обим потколенице, ОПОДЛ обим подлактице, ОНАТК - обим натколенице, ОНАДЛ - обим надлактице, ДРУЧ - дијаметар ручног зглоба, ДЛАК - дијаметар лакта, ДКОЛ - дијаметар колена, ДСКОЧ - дијаметар скочног зглоба, ДКНБИ - дебљина кожног набора бицепса, ДКНПОДЛ дебљина кожног набора подлактице, ДКННАТК - дебљина кожног набора натколенице, ДКНПОТК - дебљина кожног набора потколенице, ДКНГР - дебљина кожног набора груди, ДКНТР - дебљина кожног набора трбуха, БФМ - проценат масног ткива по Матејки, БНМ - проценат коштаног ткива по Матејки, МСМ - проценат мишићне масе по Матејки. 
У Табели 1 приказани су дескриптивни параметри на укупном узорку од 9 плесача и 14 плесачица латиноамеричких плесова, као и вредности према узрасној категорији. Резултати телесног састава, рачунати једначинама по Матејки, показују да је просечна вредност процента масног ткива код плесача $16,57 \% \pm 4,49$ (на

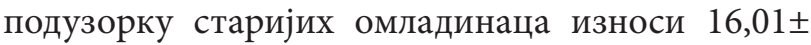
$4,8$ и сениора $16,84 \pm 4,76)$, коштаног ткива $16,11 \%$ $\pm 1,48$ (на подузорку старијих омладинаца износи $17,33 \pm 1,31$ и сениора $15,51 \pm 1,22)$ и мишића $49,41 \% \pm 3,73$ (на подузорку старијих омладинаца износи 47,97 $\pm 1,76$ и сениора $50,13 \pm 4,38$ ). Просечна вредност процента масног ткива код плесачица је 20,70\% $\pm 3,38$ (на подузорку старијих омладинки износи $21,57 \pm 3,40$ и сениорки 19,55 \pm 3,27 ), коштаног ткива $15,16 \% \pm 1,23$ (на подузорку старијих омладинки износи $15,14 \pm 1,32$ и сениорки $15,20 \pm 1,21)$ и мишића $48,06 \% \pm 3,03$ (на подузорку старијих омладинки износи 47,36 \pm $3,09$ и сениорки $48,99 \pm 2,95)$.
Плесачи показују да се телесна висина целог узорка $(1,80 \pm 0,04)$ налази у опсегу просечних висина мушкараца Србије, с тим што резултати по узрасту указују на то да просечна висина старијих омладинаца $(1,82 \pm 0,06)$ има већу вредност него сениора $(1,79 \pm 0,03)$. Интересантан је и податак да се резултати процента телесних масти мерених различитим методама разликују у већој мери, при чему је боди импеданса дала ниже вредности $(8,39)$, а једначина по Матејки приближно двоструко већу вредност $(16,57)$. Плесачице су такође у опсегу просечних висина за жене. У резултатима се уочава да се вредности процента мишићне масе налазе изнад вредности „условног човека“ и „условне жене“, према Угарковићу (Ugarković, 2004, стр. 54).

Повезаност антропометријских параметара према полу и узрасту

Претпоставка је била да постоје статистички значајне разлике између телесног састава плесача и плесачица латиноамеричких плесова у укупном узорку.

Табела 2. Компаративни статистички показатељи

\begin{tabular}{|c|c|c|c|c|c|c|c|c|c|c|c|c|}
\hline & \multicolumn{4}{|c|}{ Плесачи - плесачице } & \multicolumn{4}{|c|}{ Ст. омладинци - сениори } & \multicolumn{4}{|c|}{ С.омладинке - сениорке } \\
\hline & df & $\begin{array}{c}\text { Mean } \\
\text { Square } \\
\end{array}$ & $\mathbf{F}$ & $\mathbf{p}$ & df & $\begin{array}{c}\text { Mean } \\
\text { Square }\end{array}$ & $\mathbf{F}$ & $\mathbf{p}$ & df & $\begin{array}{c}\text { Mean } \\
\text { Square }\end{array}$ & $\mathbf{F}$ & $\mathbf{p}$ \\
\hline ТВ & 1 & ,102 & 29,275 &, $000^{\star *}$ & 1 & 0,002 & 1,050 &, 340 & 1 & 0,009 & 2,261 & ,159 \\
\hline TM & 1 & 1856,160 & 37,518 &, $000^{\star *}$ & 1 & 8,820 & 0,631 & 453 & 1 & 17,101 & 0,224 & ,644 \\
\hline БФБИА & 1 & 732,220 & 68,644 &, $000^{* *}$ & 1 & 0,222 & 0,024 &, 882 & 1 & 8,823 & 0,709 & ,416 \\
\hline БМИ & 1 & 40,377 & 11,042 &, $003^{\star \star}$ & 1 & 4,109 & 1,396 & ,276 & 1 & 1,306 & 0,309 &, 589 \\
\hline ОПОТК & 1 & 64,935 & 9,244 &, $006^{* *}$ & 1 & 0,020 & 0,016 & ,904 & 1 & 5,041 & 0,453 &, 514 \\
\hline ОПОДЛ & 1 & 46,553 & 12,219 &, $002^{\star *}$ & 1 & 17,209 & 4,621 & ,069 & 1 & 0,019 & 0,006 & ,938 \\
\hline OHATК & 1 & 12,444 & ,403 &, 532 & 1 & 33,620 & 0,659 & ,444 & 1 & 4,801 & 0,228 & ,642 \\
\hline ОНАДЛ & 1 & 127,097 & 23,802 &, $000^{\star *}$ & 1 & 0,320 & 0,121 &, 738 & 1 & 0,047 & 0,006 & 940 \\
\hline ДРУЧ & 1 & 2,452 & 24,852 &, $000^{\star *}$ & 1 & 0,020 & 0,350 &, 573 & 1 & 0,004 & 0,028 & ,871 \\
\hline ДЛАК & 1 & 4,500 & 23,253 &, $000^{\star *}$ & 1 & 0,802 & 3,918 & ,088 & 1 & 0,000 & 0,002 & 969 \\
\hline ДКОЛ & 1 & 7,518 & 25,759 &, $000^{\star *}$ & 1 & 0,020 & 0,073 & ,795 & 1 & 0,001 & 0,004 & ,949 \\
\hline ДСКОЧ & 1 & 4,928 & 35,060 &, $000^{* *}$ & 1 & 0,094 & 0,430 &, 533 & 1 & 0,019 & 0,177 & ,682 \\
\hline ДКНБИ & 1 & 22,969 & 5,971 &, $023^{\star}$ & 1 & 0,180 & 0,049 &, 830 & 1 & 2,960 & 0,681 & ,425 \\
\hline ДКНПОДЛ & 1 & 24,196 & 2,973 & ,099 & 1 & 0,681 & 0,158 & ,703 & 1 & 26,007 & 2,736 & ,124 \\
\hline ДКННАТК & 1 & 5,306 & ,251 & ,622 & 1 & 3,294 & 0,096 & ,766 & 1 & 40,415 & 3,033 & ,107 \\
\hline
\end{tabular}


Лабудовић Д., и сар., Антропометријске карактеристике и..., ФИЗИЧКА КУЛТУРА 2018; 72 (2): $200-208$

\begin{tabular}{lccccccccccccc}
\hline ДКНПОТК & 1 & 66,623 & 6,904 &, $016^{*}$ & 1 & 10,889 & 0,944 &, 364 & 1 & 0,019 & 0,002 &, 964 \\
ДКНГР & 1 & 35,822 & 6,970 &, $015^{*}$ & 1 & 8,405 & 0,977 &, 356 & 1 & 0,707 & 0,220 &, 648 \\
ДКНТР & 1 & 15,044 & 1,161 &, 293 & 1 & 0,500 & 0,030 &, 868 & 1 & 1,761 & 0,139 &, 716 \\
БФМ & 1 & 93,740 & 6,360 &, $020^{*}$ & 1 & 1,389 & $0, .061$ &, 812 & 1 & 13,938 & 1,244 &, 287 \\
БНМ & 1 & 4,946 & 2,800 &, 109 & 1 & 6,613 & 4,244 &, 078 & 1 & 0,010 & 0,006 &, 939 \\
МСМ & 1 & 10,059 &, 915 &, 350 & 1 & 9,360 & 0,642 &, 449 & 1 & 9,105 & 0,990 &, 339 \\
\hline
\end{tabular}

*статистички значајна разлика на нивоу, $05 ;{ }^{* *}$ статистички значајна разлика на нивоу ,01

Легенда: $d f$ - степен слободе, Mean Square- аритметичка средина квадрата, F- коефицијент варијансе, $p$ - значајност, ТВ - телесна висина, ТМ - телесна маса, БФБИА - проценат телесне масти мерен БИА методом, БМИ - индекс телесне масе, ОПОТК - обим потколенице, ОПОДЛ - обим подлактице, ОНАТК - обим натколенице, ОНАДЛ - обим надлактице, ДРУЧ - дијаметар ручног зглоба, ДЛАК - дијаметар лакта, ДКОЛ - дијаметар колена, ДСКОЧ - дијаметар скочног зглоба, ДКНБИ - дебљина кожног набора бицепса, ДКНПОДЛ - дебљина кожног набора подлактице, ДКННАТК - дебљина кожног набора натколенице, ДКНПОТК дебљина кожног набора потколенице, ДКНГР - дебљина кожног набора груди, ДКНТР - дебљина кожног набора трбуха, БФМ - проценат масног ткива по Матејки, БНМ - проценат коштаног ткива по Матејки, МСМ - проценат мишићне масе по Матејки.

Резултати у Табели 2 приказују да је проценат телесне масти једина од три компоненте телесног састава која показује статистички значајну разлику у односу на пол, на нивоу значајности ,05. Проценат коштаног ткива и мишића не показује статистички значајну разлику. Од измерених вредности антропометријских мера, статистички значајну разлику показују телесна висина, телесна маса, проценат масног ткива измерен БИА методом, индекс телесне масе, обим потколенице, подлактице и надлактице и сва четири дијаметра, на нивоу значајности ,01. Дебљина кожног набора потколенице и груди показује статистички значајну разлику на нивоу значајности ,05. Код осталих мера нема статистички значајне разлике.

Претпостављало се и да не постоји статистички значајна разлика између резултата плесача и плесачица две узрасне категорије, старијих омладинаца и сениора, што је анализа резултата и потврдила код оба пола.

\section{ДИСКУСИЈА}

Циљ истраживачког рада био је да се одреди телесни састав латиноамеричких плесача највишег такмичарског разреда у Србији. Узорак истраживања је обухватио 23 испитаника (плесачи, н = 9; плесачице, н = 14). Целокупни узорак, 23 испитаника, активни су такмичари више година.
Резултати су показали да БМИ има средњу вредност испод 25 код оба пола и сва четири подузорка, те се може рећи да плесачи имају нормалну ухрањеност (према Stojiljković i sar., 2012, str. 331). Такође, резултати процента масног ткива код плесача (16,57\% по Матејки) и плесачица (20,70\% по Матејки) показују да се испитаници налазе у граничним вредностима за пол и узраст, а које износе од 12 - 20\% за мушкарце и $17-26 \%$ за жене (Stojiljković i sar., 2012, стр. 329), односно од 8 - 20\% за мушкарце старости од 18 до 39 година и 21 - 33\% за жене узраста од 18 до 39 година (Остојић, цитирано према Stojiljković i sar., 2012. стр. 329). Ако се пореде добијени резултати телесног састава, они су у складу са претходним истраживањима код плесачица, док код плесача постоји мала разлика. Средња вредност процента телесне масти код латиноамеричких плесача Србије износи $16,57 \% \pm 4,49$, што је нешто виша вредност него у претходним истраживањима у којима је овај проценат износио $12,9 \% \pm 3,4$ (Raschka \& Beyer, 2015), 13,06\% $\pm 4,33$ (Liiv et al., 2013A), 13,4\% $\pm 3,3$ (Liiv et al., 2013B) и 14,4\% \pm 6,9 (Mikhailov \& Raschka, 2010). Када су у питању плесачице, просечна вредност процента масног ткива у истраживању такмичарки Србије износила је $20,70 \% \pm 3,40$ што је у потпуности у складу са претходним истраживањима у којима је ова вредност износила 21,3\% $\%$ 3,2 (Yannakoulia et al., 1999), 21,8\% $\pm 4,6$ (Raschka \& Beyer, 2015), $21,92 \% \pm 3,74$ (Liiv et al., 2013A), $22,5 \% \pm 3,2$ (Mikhailov \& Raschka, 2010) и 22,6\% $\pm 5,6$ (Liiv 
et al., 2013B). Плесачице Србије показују нешто нижу вредност процента масног ткива у односу на претходна истраживања. Ако се сагледа израчунати параметар индекс телесне масе (БМИ) у свим истраживањима, његова вредност код плесача Србије износи 23,87 док се у осталим истраживањима креће у интервалу од 22,0 до 23,1 (Raschka \& Beyer, 2015; Liiv et al., 2013A; Liiv et al., 2013B; Mikhailov \& Raschka, 2010), што je y складу и са разликама у вредностима процента телесне масти која је већа код плесача Србије. Код плесачица Србије, просечна вредност БМИ износи 21,5 , док се у осталим истраживањима кретао од 19,9 до 22,0 (Liiv et al., 2013A; Liiv et al., 2013B; Mikhailov \& Raschka, 2010; Raschka \& Beyer, 2015; Yannakoulia et al., 1999), што указује на слагање у односу на плесачице других поднебља.

Поређење вредности процента телесне масти мерене различитим методама код латиноамеричких плесача Србије показало је велике разлике у вредностима добијеним различитим методама код плесача, при чему је биоелектрична импеданса дала ниже вредности $(8,39)$ од једначине по Матејки (16,57). С обзиром да су вредности БМИ плесача Србије више у односу на остале, ове разлике могу да буду предмет неког следећег истраживања. Резултати плесачица приближно су исти у обе методе (19,95 и 20,70).

Када је у питању разлика резултата између полова, претпоставка је била да ће у свим параметрима постојати разлике. Међутим, само проценат телесне масти је показао статистички значајну разлику у методама биоелектричне импедансе и по Матејки, док проценат коштаног и мишићног ткива не показује статистички значајну разлику. Ово није у сагласности са претходним истраживањима јер су запажања ранијих истраживања показала јасне родно специфичне разлике између мушких и женских плесних извођача, које се огледају у мерама трансверзалних и циркуларних димензионалности, дебљине кожних набора, процента телесних масти, као и резултата појединачних одредби типологије (Liiv et al., 2013A; Liiv et al., 2013B; Mikhailov \& Raschka, 2010; Raschka \& Beyer, 2015).

Резултати испитивања постојања разлике између плесача различите узрасне категорије, показало је да ниједан параметар и компонента телесног састава не показују статистички значајну разлику између старијих омладинаца и сениора на нивоу значајности ,05. У ранијим истраживањима, оваква поређења нису рађена, али су испитиване разлике у односу на дужину тренирања и оне су показале да постоји неколико значајних специфичних разлика међу плесачима различитог плесног нивоа: мушкарци на вишем плесном нивоу имају мању телесну масу (није статистички значајна разлика), више позициониран сфирион (око 1,5 цм), мању ширину грудног коша (око 1,4 цм) и нижи укупни проценат телесне масти (11\% у односу на $14 \%)$ у односу на мушкарце на нижем плесном нивоу (Mikhailov \& Raschka, 2010), што би могла да буде идеја за неко наредно истраживање разлика између плесача различитог нивоа Србије на већем узорку.

Резултати испитивања постојања разлике између плесачица различите узрасне категорије, показало је да ниједан параметар и компонента телесног састава не показују статистички значајну разлику између старијих омладинки и сениорки на нивоу значајности ,05. Иако не постоје подаци из ранијих перида у вези са овом проблематиком, постоје подаци о испитиваним разликама између различитог плесног нивоа латиноамеричких плесачица. Плесачице углавном показују супротан тренд у односу на плесаче на различитим плесним нивоима. Плесачице на вишим нивоима имају већу телесну масу (не значајно), краћи труп (за исту просечну телесну висину од око 166 цм) и већи проценат укупне телесне масти (није значајно). Већина обима открива тренд раста у контрасту са плесачицама нижег плесног нивоа (Mikhailov \& Raschka, 2010). Такође, разлике у односу на друге плесне стилове указују да су латиноамеричке плесачице нешто више и теже, са мањом мишићном масом и већим процентом масне компоненте телесног састава, као и већим аеробним капацитетом у односу на балерине класичног и савременог балета (Liiv et al., 2013A; Liiv, 2014).

Различити узрасти плесача у овом истраживању могу се, условно, посматрати и као различити плесни нивои, обзиром да је узраст најчешће у корелацији са дужином тренирања, а самим тим и са нивоом извођења. Међутим, ово истраживање није показало разлике у односу на узраст плесача код оба пола. 


\section{ЗАКЉУЧАК}

Спроведено истраживање, на пригодном узорку плесача, прво је које се бавило проблемом телесног састава латиноамеричких плесача у Србији. Добијени резултати су показали структуру телесне композиције и вредности мерења антропометријских димензионалности, карактеристичних за латиноамеричке плесаче Србије највишег плесног ранга, оба пола, у две узрасне категорије (старији омладинци и сениори). Пошло се од претходних истраживања која су утврдила постојање умерено витке грађе плесача, као и разлика у односу на полну структуру.

Овим истраживањем потврђене су претпоставке у вези са телесном композицијом, узрасним разликама у оквиру истог пола, као и делимично са међуполним разликама, на узорку од 23 плесача. Такође, уочено је и да су плесачи латиноамеричких плесова просечне телесне висине и телесне масе, а добијени резултати мерења су у складу са претходним истраживањима.

\section{ЛИТЕРАТУРА}

1. Jocić, D. (1999). Plesovi. Beograd: Fakultet fizičke kulture Univerziteta u Beogradu.

2. Labudović, D. (2015). Kvalitativna analiza Standardnih plesova (Neobjavljen završni rad). Fakultet sporta i fizičkog vaspitanja.Beograd.

3. Liiv, H. (2014). Anthropometry, body composition and aerobic capacity in elite DanceSport athletes compared with ballet and contemporary dancers (Dissertationes Kinesiologiae Universitatis Tartuensis). Tartu: University of Tartu.

4. Liiv, H., Wyon, M. A., Jürimäe, T., Saar, M., Mäestu, J., \& Jürimäe, J. (2013A). Anthropometry, somatotypes, and aerobic power in ballet, contemporary dance, and dancesport. Medical Problems of Performing Artists, 28(4), 207 - 11.

5. Liiv, H., Wyon, M., Jürimäe, T., Purge, P., Saar, M., Mäestu, J., \& Jürimäe, J. (2013B). Anthropometry and somatotypes of competitive DanceSport participants: A comparison of three different styles.
Спортски резултат у дисциплини латиноамеричких плесова зависи од низа спољашњих и унутрашњих фактора, а морфолошка грађа плесача је само један од њих. Из тог разлога, нису довољна само једнократна антропометријска мерења. Неопходно је истовремено праћење резултата мерења, промена њихових вредности и утицаја тих промена на међусобни однос фактора у које спадају: телесна композиције, функционалне способности, технички ниво и резултати такмичења. Једино на тај начин је могуће уочити везу између компонената телесног састава и спортског постигнућа и тако створити слику идеалног морфолошког модела плесача којем се тежи.

\section{НАПОМЕНА}

Рад је извод из мастер рада: Лабудовић, Д. (2018). Морфотип такмичара латиноамеричких плесова Србије (Мастер рад). Факултет спорта и физичког васпитања. Београд.

HOMO - Journal of Comparative Human Biology, 65(2), $155-160$.

6. Mikhailov, B., \& Raschka, C. (2010). Anthropometrical and Sport Consitutional Comparison of Male and Female Ballroom and Latin Dancers with Regard to Different Performance Levels. Papers on Anthropology, XIX, 2010, 258-270.

7. Милидраг, С. (1998). Плес: игра, покрет, ритам. Београд: Свет књиге.

8. Pilewska, W., Pilewski, R., \& Zukow, W. (2013). Characteristics of Body Composition Highly Qualified Dancers and Dancers Latin American Style of Dance Sports in Light of Typology of Somatic A. Wanky and Kretschmer. Journal of Health Sciences (J for the Ss H), 3(5), 255-266.

9. Raschka, C., \& Beyer, K. (2015). Sports Anthropological and Somatotypical Investigation of Male and Female Latin Dancers. Papers on Anthropology, XXIV/2, 94-101. 
10. Stojiljković, S., Mitić, D., Mandarić, S., i Nešić, D. (2012). Personalni fitnes. Beograd: Fakultet sporta i fizičkog vaspitanja Univerziteta u Beogradu.

11. Taboada-Iglesias, Y., Santana, M. V., \& GutiérrezSánchez, Á. (2017). Anthropometric Profile in Different Event Categories of Acrobatic Gymnastics. Journal of Human Kinetics, 57(2017), 169179.

12. Ugarković, D. (2004). Biomedicinske osnove sportske medicine. Novi Sad: D. L. Ugarković, 2004 (Novi Sad: FB print).
13. Yannakoulia, M., Keramopoulos, A., Tsakalakos, N., \& Matalas, A.L. (2000). Body composition in dancers: the bioelectrical impedance method. Medicine \& Science in Sports \& Exercize,32(1), 228-234.

14. DanceSport For All! (2018). World Dance Sport Federation. Dostupno 20.08.2018. godine na: https://www.worlddancesport.org/About/All

Примљен: 02. 10. 2018. Прихваћен: 24. 12. 2018. 